\title{
ATIVISMO DE ESQUERDA NAS REDES SOCIAIS: CONTRADIÇÕES DAS NOVAS TRINCHEIRAS DA LUTA POLÍTICA
}

\author{
Left-wing activism in social media: contradictions of the new trenches of \\ political struggle
}

Vanessa Tavares Dias'

\begin{abstract}
Resumo
Esse texto é resultado de pesquisa teórico-empírica, feita ao longo de quatro anos, sobre os novos repertórios do ativismo político de esquerda nas redes sociais. A pergunta que move a análise é: a resistência deste campo político, organizada nas mídias virtuais, tem sido eficiente para difundir visões de mundo progressistas e produzir uma reforma intelectual e moral num nível universal? Para a análise, partimos da perspectiva dialética que aponta para o movimento contraditório entre as formas de resistência à ordem capitalista por meio das novas tecnologias de comunicação versus a função dessas tecnologias no processo de ampliação constante do capital. Por meio da filosofia da práxis de Gramsci, concluímos que as lutas políticas à esquerda podem ser reprodutoras ou transformadoras da ordem, mas são sempre combates que fazem avançar as potencialidades da história.
\end{abstract}

Palavras-chave: Redes sociais; Tecnologias de comunicação; Ciberativismo; Ativismo de esquerda; Filosofia da Práxis.

\begin{abstract}
This article is the result of a four-year theoretical-empirical research about the new repertoires of leftist political activism in social media. The starting question is: has the resistance of this political field, organized in virtual media, been effective in spreading progressive worldviews and producing intellectual and moral reform on a universal level? For the analysis, we start from the dialectical perspective that points to the contradictory movement between the forms of resistance to the capitalist order through the new technologies of communication versus the function of these technologies in the process of constant expansion of capital. From Gramsci's philosophy of praxis, we conclude that left-wing political struggles can be reproductive or transforming order, but it will always be a struggle that makes advance the potentialities of history.
\end{abstract}

Keywords: Social networks; Communication technologies; Cyber-activism; Leftist activism; Philosophy of Praxis.

\footnotetext{
1 Doutora em Sociologia pelo Instituto de Estudos Sociais e Políticos da Universidade do Estado do Rio de Janeiro (IESP-UERJ). Mestre em Sociologia e graduada em Ciências Sociais pela Universidade Federal do Rio de Janeiro (UFRJ). Professora adjunta da Universidade Federal de Alfenas (UNIFAL-MG). Coordenadora do Laboratório de Estudos do Trabalho e dxs Trabalhadorxs (LETT-UNIFAL-MG) e pesquisadora colaboradora do Núcleo de Pesquisas e Estudos do Trabalho (NUPET-UERJ). E-mail: vanessa.dias@unifal-mg.edu.br
} 
Ativismo de esquerda nas redes sociais: Contradições das novas trincheiras da luta políticaVanessa Tavares Dias

Os homens fazem a sua própria história, mas não a fazem segundo a sua livre vontade; não a fazem sob circunstâncias de sua escolha e sim sob aquelas com que se defrontam diretamente, legadas e transmitidas pelo passado.

$\operatorname{Karl} \operatorname{Marx}^{2}$

\section{Introdução}

A partir dos anos noventa do último século, as novas tecnologias de comunicação, desde a telefonia móvel à internet, iniciaram um processo decisivo de transformação das formas de comunicação global. No ciberespaço, por meio de mensagens pessoais, blogs e microblogs, individuos e grupos sociais produzem e difundem narrativas que circulam nas redes interativas de maneira descentralizada e desterritorializada, o que significa dizer que, ao contrário dos meios unidimensionais, na esfera digital as produções textuais e audiovisuais partem de muitos emissores para muitos receptores e circulam num ambiente virtual em esfera planetária.

No universo das novas tecnologias de comunicação e de informação, as redes sociais - Facebook, Twitter, MySpace, Instagram, bem como o aplicativo multiplataforma Whatsapp, entre outras - ligam pessoas numa tecitura de interações sociais. Cada indivíduo que compartilha um documento em quaisquer dessas plataformas é capaz de retransmiti-lo a novos círculos de pessoas, potencializando o seu alcance. As mídias corporativas reequiparam-se para atuar também na web e muitos debates virtuais, que confrontam informações difundidas pelo jornalismo off-line, acabam por forçálas a incluir certos assuntos em suas pautas diárias. Os novos espaços intercomunicativos também permitem a mediação de atores políticos de novo tipo, produtores e avaliadores de conteúdo, debatedores em conversações coletivas e "influenciadores digitais". Estes são denominados nesses termos em virtude do amplo alcance dos conteúdos divulgados em seus canais de comunicação, os quais norteiam as opiniões de um público gigantesco. A telemática também criou novas possibilidades de socialização de conhecimento e consolidou novas formas de comércio. Além disso, tem se colocado como agente central nas dinâmicas eleitorais e no funcionamento

\footnotetext{
2 MARX, Karl. O 18 Brumário e Cartas a Kugelmann. Rio de Janeiro: Ed. Paz e Terra, 1986, p. 17.
} 
Ativismo de esquerda nas redes sociais: Contradições das novas trincheiras da luta política | Vanessa Tavares Dias

das instituições políticas dos Estados nacionais. Esses inúmeros aspectos evidenciam mudanças que impactam diferentes dimensões da vida social.

Simultaneamente, o ativismo impulsionado pelos meios digitais tem embaralhado o modus operandi das relações concertadas da política tradicional. Para o campo político à esquerda ${ }^{3}$, as redes sociais tornaram-se, em definitivo, novas trincheiras de lutas, possibilitando a formação de novos coletivos e forjando novas formas de ativismo ${ }^{4}$. Ainda que a adesão não tenha sido instantânea (SEVERO et. al., 2017), é preciso reconhecer que essas novas mídias tornaram-se, a contar pelo menos da última década até o presente, um campo de batalhas ocupado por partidos, movimentos sociais e organizações desse espectro político, dispostos a estimular mobilizações e a disputar prevalência de narrativas com diferentes adversários do campo oposto. Essa participação é deveras dinâmica e o repertório de atuação se altera a cada momento, numa extraordinária rapidez.

Todavia, já nos anos 90, Lévy (1997) advertia que "crer numa total disponibilidade das técnicas e do seu potencial para os indivíduos e colectividades [sic] pretensamente livres, esclarecidas e racionais será acalentar ilusões" (LÉVY, 1997, p. 27). Ainda que as redes sociais tenham aberto flancos de comunicação para a resistência de esquerda, o espaço cibernético e a interação via aplicativo Whatsapp têm sido disputados por diferentes interesses, que vão desde os econômicos das grandes corporações, aos imperativos de monopólio da indústria cultural e às ideologias de cunho neoliberal, antidemocráticas e anticomunistas. Como a história recente tem demonstrado, o universo virtual amplifica e fortalece os brados da antítese ultraconservadora, os quais têm sido até o momento muito eficientes na produção de consensos em torno de seus projetos de poder. As narrativas

\footnotetext{
3 Os debates sociológicos e histórico-políticos que têm a esquerda como objeto possui grande complexidade, e seu mapeamento não caberia nos limites deste texto. Por ora, partimos de um pressuposto conceitual, com base na tipologia de Bobbio (2001), que distingue "esquerda externa", revolucionária, e "esquerda interna", reformista. A primeira teria como princípio a luta pela ruptura da ordem capitalista. A segunda dedicar-se-ia aos combates em favor da justiça social nos marcos do próprio capitalismo. Nesse texto, empregamos os termos ciberativismo e ativismo de esquerda com a intenção de alcançar a pluralidade das formas de militância de esquerda, em todas as suas gradações. 4 Hackerismo, Hackeanismo ou hackerativismo, por exemplo, são termos utilizados para definir ações diretas de ativistas que invadem sítios oficiais de governos e de grandes corporações com o propósito de sequestrar informações e/ou interferir em seu funcionamento.
} 
Ativismo de esquerda nas redes sociais: Contradições das novas trincheiras da luta políticaVanessa Tavares Dias

propagadas nas redes sociais pelos campos da direita e da extrema direita sobre determinadas pautas da esquerda, tais como direitos humanos ou principios básicos da democracia burguesa, têm atraído um número enorme de adeptos e provocado engajamentos diversos, produzindo efeitos anticivilizatórios devastadores.

Além de não ser um espaço de pensamento livre e racional, a "divisão digital", registrada por Castells $(2012$; 2003), aponta para acesso desigual da $w e b$ por individuos de classes sociais diferentes, de países de capitalismo central e de capitalismo periférico, por habitantes do campo e das pequenas cidades em relação aos residentes nas grandes metrópoles, por diferentes gerações e por distintas etnias. Tilly e Wood (2010) corroboram essa questão ao afirmarem que as relações comerciais e politicas presentes na web permitem unir "comunidades" de uma maneira inteiramente nova, realizando, contraditoriamente, o isolamento daqueles que não fazem parte do círculo de relações. Tal fenômeno revela que as informações que circulam na web, ainda que consigam alcançar milhões de pessoas, encontram limites para penetrar em grupos excluídos. Aqueles que não encontram problemas de acesso às tecnologias digitais se deparam com outro obstáculo para acompanhar debates em rede. Trata-se da formação de círculos concêntricos de interações, as chamadas "bolhas", para os quais é direcionado apenas um número limitado de informações, fenômeno que impede os usuários de conhecerem todos os lados de uma polêmica.

Silveira (2014) e outros autores (PARISER, 2012; LEMOS e LÉVY, 2010; TILLY e WOOD, 2010, CASTELLS, 2003, LÉVY, 1997) denunciam o infocontrole - controle direto e indireto de Estados, agências internacionais ${ }^{5}$ e corporações sobre os conteúdos da web. Silveira (2014) aponta para o fato de que, não obstante os protocolos das neotecnologias garantam a liberdade de expressão, eles consentem que determinadas agências tenham acesso a informações privadas dos usuários com objetivos diversos, que vão desde

\footnotetext{
5 Edward Snowden tornou-se o mais importante hackerativista da atualidade. Ex-administrador de sistemas da CIA, revelou para o mundo os arquivos secretos de agências de espionagem norteamericanas, denunciando o fato de que o mundo está sendo vigiado. Isso vale tanto para cidadãos comuns como para governantes de nações. O "caso Snowden" está registrado no livro Os arquivos de Snowden, de Luke Harding (HARDING, L. Os Arquivos Snowden: a história do homem mais procurado do mundo. LeYa, Rio de Janeiro, 2014).
} 
Ativismo de esquerda nas redes sociais: Contradições das novas trincheiras da luta política | Vanessa Tavares Dias

repressão a crimes cibernéticos a fins eleitorais e mercantis. Recentemente, analistas têm retratado o papel desastroso das mídias sociais para as democracias modernas, especialmente o Whatsapp, cujos conteúdos duvidosos ou falsos, retransmitidos entre usuários sem filtragem ou averiguação por terceiros, vêm interferindo diretamente em processos eleitorais (BOVET; MAKSE, 2019, ALLCOTT; GENTZKOW, 2017, WOOLLEY; GUILBEAULT, 2017) ${ }^{6}$. No início de 2018 , a mídia internacional denunciou a venda de informações pessoais de milhões de usuários do Facebook para empresas de consultoria politica, entre as quais a Cambridge Analytica, responsável pela campanha presidencial de Donald Trump. A estratégia dessa empresa em particular consiste em criar um perfil psicológico de potenciais eleitores, classificando-os segundo seus interesses, crenças e personalidades. Em seguida, ela estabelece filtros por meio dos quais envia, via mídias digitais, propagandas politicas personalizadas, com potencial para afetar a subjetividade de cada pessoa e, com isso, alcançar determinados resultados em eleições (REHMAN, 2019).

Nossa análise parte do princípio de que os novos repertórios da luta politica, a desigualdade de acesso à internet, o infocontrole, a circulação de notícias falsas (fake news) e o avanço da ideologia de direita e de extrema direita, entre outros aspectos, expressam certa dimensão da conjuntura específica da luta de classes no atual contexto das relações capitalistas de produção. Nesse sentido, diferentemente da ideia de que a ciência e a técnica (que são parte das forças produtivas materiais) se desenvolvem de modo contraditório às relações de produção, as novas tecnologias de comunicação virtual devem ser concebidas como instrumentos criados e governados sob o predomínio do capital e, portanto, relacionados às exigências do capitalismo reestruturado: aumento da transformação de trabalho vivo em trabalho morto e outras formas renovadas de alienação e de exploração ${ }^{7}$. As resistências

\footnotetext{
6 O referendo do Brexit ("British exit"), as eleições nos Estados Unidos, em 2016, e as eleições no Brasil, em 2018, são alguns dos exemplos.

7 Conforme Santos (2003), a aliança entre capital e tecnociência revela a capacidade do capitalismo de assenhorear-se da dimensão virtual da realidade, sendo a "virada cibernética" a ocasião para o capital global expandir-se de tal forma a, inclusive, apropriar-se do futuro.
} 
Ativismo de esquerda nas redes sociais: Contradições das novas trincheiras da luta políticaVanessa Tavares Dias

possiveis, reelaboradas nas disputas online, não devem ser pensadas à parte dessa totalidade complexa.

Considerando-se que as neotecnologias de comunicação encontram-se no contexto maior das contradições do capitalismo avançado, este texto pretende expor algumas reflexões sobre os usos da internet e em particular das redes sociais pelo ativismo de esquerda, salientando a dialética entre as formas de resistência à ordem pela tecnologia versus a função da tecnologia a serviço da ampliação constante do capital. Em síntese, nosso objetivo é compreender, à luz da filosofia da práxis, os progressos e os limites das novas tecnologias para a ampliação do espaço discursivo da esquerda.

\section{Comunicação: base econômica e arena de lutas}

Em suas análises sobre o capitalismo, Marx e Engels consideraram a evolução da tecnologia como parte do processo de transformação das forças produtivas e, portanto, da transformação da ordem econômica e politica em direção a sua superação. Desta feita, como os autores apontaram em $A$ Ideologia Alemã (MARX; ENGELS, 2007), a emancipação humana ocorrerá não como ato do pensamento ou produto do idealismo, mas como resultado complexo das transformações materiais no decorrer do processo histórico, na sucessão de gerações que "sobre o ombro da precedente, desenvolveram sua indústria e seu comércio e modificaram sua ordem social de acordo com as necessidades alteradas" (MARX; ENGELS, 2007, p. 30). Nessa mesma obra, ao tratarem as condições para a revolução proletária, os autores observaram que:

(...) transcorre sempre um longo periodo antes que os indivíduos possam se unir, sem contar que, para essa união - quando não for meramente local -, os meios necessários, as grandes cidades industriais e as comunicações acessiveis e rápidas, têm de primeiro ser produzidas pela grande indústria; e, por isso, todo poder organizado em face desses indivíduos que vivem isolados e em relações que diariamente reproduzem o isolamento só pode ser vencido após longas lutas (MARX; ENGELS, 2007, p. 62, grifos nossos).

No curso do aperfeiçoamento dos instrumentos de produção, tema presente também no Manifesto do Partido Comunista (MARX; ENGELS, 2010), os pensadores destacaram a importância do progresso dos meios de comunicação: navegação a vapor, estradas de ferro e telégrafo elétrico. O avanço da comunicação intensificaria o contato entre os trabalhadores para 
Ativismo de esquerda nas redes sociais: Contradições das novas trincheiras da luta política | Vanessa Tavares Dias

além dos limites nacionais, auxiliando sobremaneira a sua organização e a luta revolucionária. Nesse sentido, a classe explorada apropriar-se-ia da ciência e da técnica da sociedade burguesa em favor de sua própria libertação.

Em síntese, a inovação material - que, em Marx e Engels, não significa mera metamorfose de instrumentos técnicos, mas mudanças sociais e históricas ocasionadas pela produção - é parte do processo do desenvolvimento das forças produtivas, o que inclui o desenvolvimento do proletariado em direção à sua emancipação. Apesar disso, contrariamente às perspectivas positivistas e revisionistas que defendem o resultado predeterminado desse movimento, Katz (1997) acredita que não é possível prever a emancipação humana como resultado da evolução tecnológica e científica. Ou seja, não é possivel pressupor que o melhoramento continuado da tecnologia seria acompanhado na mesma medida pela evolução da consciência. A visão determinista desse processo, segundo o mesmo autor, deixa de lado o fato de que as forças produtivas estão sujeitas às contradições do modo de produção e, portanto, são engendradas pelas leis da acumulação. Para Katz, nem a tecnologia determina o curso dos acontecimentos, nem os indivíduos constroem autonomamente as alternativas otimizadoras da revolução.

Antes de Katz, Magaline (1977) já havia estabelecido críticas aos marxistas revisionistas e à sua filosofia do "progresso humano" em geral. Nela, as relações de produção seriam consideradas o elemento relativamente estável da base econômica, enquanto as forças produtivas teriam um duplo papel: 1) seriam o motor da transformação histórica; 2) prenunciariam e preparariam o modo de produção superior. Sua crítica reside no fato de que, nesse caso, as forças produtivas materiais e/ou subjetivas seriam tomadas em si, independentemente das relações sociais históricas no interior das quais essas forças agiriam e funcionariam. Conforme Magaline:

Admite-se igualmente que as relações de produção "imprimem" às forças produtivas uma certa "estrutura", mas esta "estrutura" não é senão uma "forma", uma "marca", um rasto deixado atrás de si pelas relações de produção, de modo que o desenvolvimento das forças produtivas não é por isso afectado [sic] na sua "essência" (MAGALINE, 1977, p. 22). 
Ativismo de esquerda nas redes sociais: Contradições das novas trincheiras da luta políticaVanessa Tavares Dias

Na construção dessa perspectiva - continua -, os teóricos da revisão se aproximariam do que Marx chamou de "fetichismo do capital", ou seja, apareceriam em suas reflexões formas históricas da produtividade social como um conjunto heteróclito de "coisas" em separado: máquinas, tecnologia, ciência, organização do trabalho, entre outras. Esse fetichismo se estenderia à defesa do progresso técnico, da produção, do crescimento econômico e da "inovação", isto é, do incremento técnico-científico autônomo (excluindo, portanto, a separação entre ciência e produtor) em favor da transformação revolucionária. Nesse exato sentido, o desenvolvimento material das forças produtivas colocar-se-ia a serviço da luta proletária na direção do projeto emancipatório da classe, substituindo a luta de classes relegada ao papel de coadjuvante (MAGALINE, 1977).

A comunicação e os seus meios materiais são, na análise de Williams (2011), intrínsecos às formas humanas de trabalho e à organização social. Tanto a linguagem quanto os meios técnicos de transmiti-la estão diretamente relacionados ao desenvolvimento histórico e, portanto, conexos ao desenvolvimento das forças produtivas de um determinado período. Tomando de empréstimo essa concepção, podemos afirmar que as tecnologias modernas empregadas nas formas interativas de comunicação são produto e, ao mesmo tempo, meios de produção de diferentes processos produtivos. Softwares, hardwares, processadores, discos magnéticos são valores de uso produzidos no âmbito da divisão social e sexual do trabalho. Do mesmo modo, são meios de produção apropriados à criação de novos valores de uso. Tais tecnologias configuram-se instrumentos de inscrição e amplificação da linguagem trocada nos processos comunicacionais e, portanto, trocada nas relações sociais através das quais os indivíduos expressam pensamentos e sentimentos emoldurados pela técnica.

Todavia, como observa Williams (2011), a ideologia burguesa exclui a comunicação de uma análise materialista, pressupondo-a, simplesmente, como maneiras de transmitir mensagens ou informações por sujeitos abstratos em intercâmbios não problemáticos. Os sujeitos, segundo essa perspectiva, participariam de situações de sociabilidade, sendo a comunicação uma forma estrita de "socialização" ou de "processo social" abstrato. Da 
Ativismo de esquerda nas redes sociais: Contradições das novas trincheiras da luta política | Vanessa Tavares Dias

mesma forma, tal ponto de vista, segundo o marxista galês, prescindiria de uma análise sobre as diferentes relações sociais dentro de cada grupo social, entendendo que todos os indivíduos participantes da situação de comunicação teriam algo a dizer.

Outro equívoco, notadamente presente no campo marxista, ainda segundo esse autor (WILLIAMS, 2011), é o uso do termo "produção" limitado à produção de mercadorias ou produção para o "mercado". Nesse sentido, reafirma-se certa perspectiva que separa linguagem cotidiana, formas de comunicação e produção material da vida. Williams procura demonstrar a impostura dessa separação, que está:

relacionada a, e mesmo dependente de, formulações mecânicas de base e da superestrutura, nas quais o papel inerente dos meios de comunicação em toda a forma de produção, incluindo a produção de objetos, é ignorada, e a comunicação se torna um processo de segunda ordem ou uma segunda etapa, que entra no processo apenas após estabelecerem-se das relações produtivas e sociomateriais decisivas (WILLIAMS, 2011, p. 73).

Gramsci tornou-se, grosso modo, um teórico marxista com olhar voltado para a superestrutura. Todavia, a filosofia da práxis - termo usado pelo pensador para, entre outros aspectos, distinguir a sua filosofia das interpretações vulgares do materialismo histórico - não esbarra no erro comum, apontado por Williams (2011), que separa estrutura e superestrutura. A filosofia da práxis, contrariamente, enfatiza a relação dialética base-superestrutura, sendo esta relação o seu objeto próprio. Nesse sentido, o comunista italiano encontra nexo fundamental entre a "vontade humana", a ideologia, a ciência e a cultura, ou seja, a superestrutura e a estrutura econômica, que formam juntas uma organização social concreta. "Para a filosofia da práxis - afirma -, o ser não pode ser separado do pensar, o homem da natureza, a atividade da matéria, o sujeito do objeto; se se faz esta separação, cai-se numa das muitas formas de religião ou na abstração sem sentido" (GRAMSCI, 2004, p. 175).

Para o marxista sardo, o Estado é formado por dois planos no que respeita à superestrutura, denominados sociedade civil e sociedade política, que constituem o Estado integral. O pensador extrai a ideia hegeliana de que 
Ativismo de esquerda nas redes sociais: Contradições das novas trincheiras da luta políticaVanessa Tavares Dias

sociedade civil é parte do Estado e ali os indivíduos são educados para a "vontade coletiva" (LIGUORI, 2017). Contudo, ele não perde a dimensão do conteúdo de classe do mesmo objeto, entendendo o Estado como organização econômico-política da classe burguesa, e a sociedade civil como parte do Estado que representa, em linhas gerais, o campo da luta das classes. Nesse sentido, Gramsci (2007a) considera sociedade civil a base material onde se encontra o complexo de relações ideológicas, culturais e intelectuais e onde a luta política ocorrerá através dos aparelhos privados de hegemonia, de partidos políticos e de outros organismos que não são propriamente partidos, mas que funcionarão como se fossem. Essas agências com conteúdo particular irão atuar na produção de valores morais e condutas com o fim de produzir o consenso. Cabe ressaltar que distintas instituições - tanto as representantes da classe dominante, como as da classe subalterna -, ainda que detenham recursos e oportunidades de ação diferenciadas, participam da mesma luta política por hegemonia que ocorre na dimensão civil do Estado. Uma vez que todas elas estão no mesmo campo de lutas, não faz sentido utilizar o termo "contra-hegemonia". Toda a luta, em sua perspectiva, é, por conseguinte, luta por hegemonia.

Gramsci (2007a) compreende que em sociedades onde a sociedade civil é complexa a esfera ampliada do Estado torna-se arena onde as classes e as frações de classe, dominantes e dominadas, formulam ideologias, cumprem funções educativas, agem na formação da consciência e elaboram filosofias objetivando alcançar a unidade de toda sociedade em torno de uma visão de mundo. A sociedade civil é, portanto, o campo de lutas onde agências disputam ideias e os sujeitos vivenciam práticas e expectativas que incidem sobre a totalidade da vida. Podemos inferir, a partir dessa definição, que a comunicação é fenômeno privilegiado dessas lutas; por meio dela os sujeitos difundem ideias e constroem estratégias discursivas visando à produção de consenso.

Todavia, partindo da relação entre forças produtivas e relações de produção, chegamos à premissa de que os instrumentos usados para realizar a comunicação, assim como o próprio conteúdo compartilhado, estão imersos na ordem social capitalista. Logo, são parte da lógica do processo de 
Ativismo de esquerda nas redes sociais: Contradições das novas trincheiras da luta política | Vanessa Tavares Dias

reprodução e ampliação do capital. A comunicação em geral e a comunicação por meio das tecnologias são fenômenos que se encontram na exata relação estrutura-superestrutura, produto e meio de produção, mercadoria e produto social, reprodução e transformação, dispositivo de precarização do trabalho e desenvolvimento das forças produtivas, as quais, como dito acima, estão sujeitas às contradições do modo de produção. Desta feita, os processos comunicacionais precisam ser examinados como meios sociais de produção, incluindo "todo o complexo das forças produtivas e relações sociais dentro das quais eles são desenvolvidos e empregados” (WILLIAMS, 2011, p. 72).

Em resumo, as neotecnologias de comunicação são capazes de ampliar o contato entre os homens, estabelecendo maior socialização das forças produtivas subjetivas; entretanto, os conteúdos e as formas de transmissão permanecem limitados pela própria função das tecnologias nas sociedades capitalistas e pelas condições materiais de um determinado tempo histórico. Colocando de outra forma, a dinâmica que ocorre no microssistema social, no que tange especialmente às disputas de narrativas, não pode ser pensada dissociada do macrossistema tecnológico vinculado à reprodução capitalista a comunicação é estrutura e superestrutura; é força produtiva e relações de produção. No entanto, seguindo as formulações de Gramsci (2004, 2007a, 2007b), o campo da comunicação no interior da dimensão basesuperestrutura constitui uma esfera da arena das lutas e combates em torno da hegemonia. Mesmo operando sob a hegemonia das ideias da classe dominante, é campo da práxis e esfera própria da luta de classes. Competenos analisar essa contradição.

\section{Produção informatizada e subsunção do trabalho}

O fim dos anos 70 marca um novo ciclo do capitalismo, decorrente de uma nova crise da acumulação. A fórmula criada pela engenharia do capital para retomar a taxa de lucro e intensificar a extração de mais-valor ficou conhecida como reestruturação produtiva, consistindo em alterações administrativas, politicas e econômicas, no âmbito do Estado e das empresas, que resultaram, entre outros aspectos, na precarização das condições de 
Ativismo de esquerda nas redes sociais: Contradições das novas trincheiras da luta políticaVanessa Tavares Dias

existência da classe trabalhadora. Desde então, o bloco no poder tem fortalecido o aparato coercitivo contra os trabalhadores e, ao mesmo tempo, através dos seus intelectuais orgânicos, difundido novas ideologias condizentes com os interesses do capital.

Uma das táticas propaladas pelo discurso dominante, segundo Antunes (2007), apresenta a empresa flexivel, "liofilizada"8, com avançado maquinário técnico-científico substituindo parte do trabalho vivo, como sinônimo de empresa moderna. Esse discurso, segundo o autor, instalou-se no campo acadêmico, onde intelectuais do liberalismo propõem teorias sobre o fim da sociedade do trabalho em defesa de uma abstrata "sociedade do conhecimento", na qual o trabalho braçal estaria cedendo lugar em definitivo ao trabalho intelectual.

É na órbita desse novo cenário do capitalismo reestruturado e da ideologia liberal renovada que são difundidas as tecnologias digitais e em rede. Ainda que a sua invenção, como analisam Castells (2003) e Lévy (1997), tenha se dado num cenário tensionado entre inventividade e autonomia dos cientistas versus interesse da grande indústria, as neotecnologias foram amplamente incorporadas à produção de base flexível, incidindo sobre a produção e a reconfiguração de sua organização. Mediante a grande vitrine que notabiliza as tecnologias digitais - repetindo os tempos áureos de celebração das maravilhas da Indústria -, nota-se a formação de uma geração "informatizada", arrebatada pela tecnologia-fetiche, educada e socializada pelas plataformas dos jogos eletrônicos. O mundo social, para a juventude, ganha um novo sentido estético, temporal, espacial. Consequentemente, as neotecnologias conseguem, segundo a análise de Wolff (2009), não apenas treinar capacidades físicas dos futuros trabalhadores, mas também programar as suas habilidades cognitivas segundo os interesses do "mercado":

É assim que a maquinaria informática possui uma peculiaridade essencial quando cotejada com as maquinarias anteriores: a transformação da cognição em insumo do processo produtivo. Desde tal mudança, a reificação do trabalhador deixa de ser expressa pelo

\footnotetext{
8 O termo liofilização organizativa foi tomada de Juan J. Castillo (CASTILLO, Juan J. Sociologia del Trabajo, CIS, Madri, 1996; CASTILlO, Juan J. "A la Búsqueda del Trabajo Perdido", in Perez-Agote, A. e Yucera, I., Complejidad y Teiria Social, CIS, Madri, 1996) por Ricardo Antunes com vistas a explicitar a diminuição ou a eliminação de unidades produtivas nas empresas por meio de terceirização, 'enxugamento' ou transferência, de forma a "secar" o trabalho vivo, criando a empresa maquinal, cuja produção é preponderantemente realizada pelo trabalho morto.
} 
Ativismo de esquerda nas redes sociais: Contradições das novas trincheiras da luta política | Vanessa Tavares Dias

intento de convertê-lo em "homem-máquina", tal como no taylorismofordismo e se configura como uma tentativa de se humanizar a máquina desde o projeto de uma inteligência artificial que deve ser constantemente alimentada de dados por um "trabalho informacional" (WOLFF, 2009, p. 102).

Antunes (2007) revela, igualmente, que o desenvolvimento dos softwares transferiu determinadas atividades típicas do saber intelectual e cognitivo para a maquinaria informatizada. Esse fenômeno converteu capacidades intelectuais em linguagem tecnológica e acentuou a transformação de trabalho vivo em trabalho morto. No entanto, uma vez que a máquina "não pode eliminar cabalmente o trabalho humano, ela necessita de uma maior interação entre subjetividade que trabalha e a nova máquina inteligente" (ANTUNES, 2007, p. 29). Quanto mais a empresa se informatiza observa -, mais se forma um conjunto de trabalhadores com competência e qualificação em relação à gestão do conhecimento. Por outro lado, forma-se, simultaneamente, uma massa de trabalhadores precarizados: assalariados de serviços, contingentes de trabalhadores terceirizados e temporários, subcontratados, operadores de telemarketing e call center, digitalizadores de empresas financeiras, motoboys, entre outros.

Assim sendo, a cibernética, como o fordismo ${ }^{9}$ no passado, tem modificado capacidades cognitivas e capturado subjetividades com vistas a, entre outros aspectos, preparar os sujeitos para o mundo da produção. Nesse sentido, trabalhadores são socializados no universo tecnológico e, ainda que prevaleça a promessa da formação de uma "sociedade do conhecimento", continuam alienados e subsumidos ao domínio da divisão social do trabalho. Dito isso, é possível mais uma vez concluir a relação compativel entre o desenvolvimento das forças produtivas materiais e das forças produtivas subjetivas (máquinas e homens, respectivamente) e as relações de produção.

\footnotetext{
${ }_{9}^{9}$ Quando analisou a peculiaridade do fordismo, Gramsci (2007b) entendeu que os sistemas de produção em massa exigiam um tipo de mentalidade e formas especificas de vida que eram fundamentais para a manutenção do próprio sistema produtivo, notando que, para integrar-se à produção, o sujeito deveria ter características pessoais adaptadas às novas exigências e formas de vida plenamente aceitas pela rotina da fábrica, sendo esta, portanto, uma relação mútua. O americanismo, por seu turno, é o nome dado pelo pensador à cultura intrínseca ao industrialismo fordista/taylorista, que se ampliava para fora dos muros da fábrica e que produzia esse sujeito de novo tipo.
} 
Ativismo de esquerda nas redes sociais: Contradições das novas trincheiras da luta políticaVanessa Tavares Dias

Em resumo, ao contrário do que pensavam os autores revisionistas criticados por Magaline (1977), no capitalismo, o progresso tecnológico visa, em primeiro lugar, à reprodução e à reificação. Portanto, o conteúdo e as novas formas de comunicação informatizadas são parte da conexão material entre os homens que expressam ideias, representações e consciência, enredadas à atividade e às condições materiais do presente. Todavia, se a tecnologia de comunicação serve aos interesses da acumulação capitalista, é também expressão da cultura, mediadora da relação homem-realidade e, logo, condição específica da práxis.

\section{Reprodução e práxis}

Em linhas gerais, como enfatizamos desde o início, o ciberativismo de esquerda está circunscrito aos protocolos da internet e aos seus recursos técnicos. Do mesmo modo, o campo de atuação da esquerda nas redes sociais, ainda que extenso, restringe-se a um público limitado devido à "divisão digital" e à formação de "bolhas" de interação. As narrativas de enfrentamento ao campo antagônico operam sob o infocontrole, sendo alvo de censura e fonte de informação para ações de agências públicas e empresas privadas.

Como espaço de reprodução das relações sociais capitalistas, as mídias digitais apresentam uma conexão particular com o mundo das mercadorias. É possivel notar tal mercadorização quando da oferta cotidiana de produtos enviados aos usuários das redes sociais por empresas comerciais. Todavia, o mesmo fenômeno parece igualmente visível na esfera dos combates diários de contrainformação. Grohmann (2014) observa que as vozes que circulam no ciberespaço tornam-se commodities disputadas no "mercado" das interações. Isto quer dizer mais precisamente que o fluxo inicialmente descentralizado dos discursos vai sendo reajustado, de modo a que algumas vozes, especialmente aquelas de personalidades com alguma projeção popular, intelectual e/ou política, tenham as suas publicações entre as mais comentadas e repetidas pelos usuários das redes, inclusive pelos ativistas de esquerda. Embora não eliminem as interações horizontais, as publicações concorridas expressam, em parte, o retorno à verticalização de ideias, articuladas por sujeitos particulares. 
Ativismo de esquerda nas redes sociais: Contradições das novas trincheiras da luta política | Vanessa Tavares Dias

Outro aspecto, notado por Prudêncio (2008), revela que alguns coletivos de mídias "alternativas" atuantes especialmente no ciberespaço, ainda que se inscrevam na batalha da contrainformação em confronto direto com a mass media, acabam por repetir padrões de comunicação presentes no jornalismo dominante. Nesse sentido, o termo "alternativo" representa muito mais a guerra de posição estabelecida por esses meios, do que necessariamente alguma proposta inovadora de jornalismo. Esses profissionais, segundo a autora, "apostam na linguagem referencial do jornalismo para obter mais credibilidade e interferir pragmaticamente nos rumos das decisões políticas" (PRUDÊNCIO, 2008, p. 72).

Afora os exemplos acima, outros elementos experimentados no cotidiano das interações virtuais da militância reafirmam a rotina da reprodução: compartilhamento de matérias publicadas pelas mídias corporativas que, malgrado sejam, em muitos casos, um dos principais alvos de crítica de ativistas, acabam por pautar, frequentemente, o assunto debatido nas conversações coletivas; mercantilização de informações, repetidas, "consumidas" e rapidamente substituídas por novas tragédias cotidianas; hibridismo acentuado do conteúdo, que acaba por entretecer o emaranhado confuso de informações que formam o senso comum.

Ademais, as ações da militância de esquerda têm enfrentado um oponente bastante complexo. As notícias falsas, popularmente chamadas de fake news, circulam velozmente na web e em aplicativos da telefonia móvel, alcançando milhões de pessoas com acesso a esses serviços. Blogs pessoais, empresas e jornais online, entre outros, têm se especializado em produzir e difundir informações inverídicas e, em alguns casos, completamente inverossímeis. Com ajuda de robôs ${ }^{10}$, de acordo com Ferrara et. al (2016), essas informações são enviadas para usuários das redes e podem dar a

\footnotetext{
10 Um robô ou bot - apelido para robot, robô em inglês - é um algoritmo de computador cuja finalidade é produzir conteúdo de forma programada e automática nas mídias sociais. Os robôs podem ter meramente a função de agregar conteúdo ou podem ser usados por empresas como respondedores automáticos. Também podem ser utilizados para criar perfis falsos e imitar comportamentos humanos para interagir com usuários da $w e b$. Uma de suas funções é enviar notícias (falsas ou não) de forma a redirecionar publicações, criar popularidade de algumas ideias e, assim, produzir uma visão de mundo particular (FERRARA et. al., 2016).
} 
Ativismo de esquerda nas redes sociais: Contradições das novas trincheiras da luta políticaVanessa Tavares Dias

impressão de que certas opiniões são altamente populares, amplificando a audiência sobre uma determinada concepção de mundo. A criação e a circulação de notícias falsas também têm sido incorporadas por certos sítios da internet considerados de esquerda, o que acaba motivando sujeitos desse campo político a repetir a prática de compartilhamento de informações sem o respaldo factual de outras fontes jornalísticas.

Todavia, se a comunicação em rede é parte do aparato tecnológico voltado para reificação e reprodução, é igualmente práxis. E como forma nãoalienada da atividade humana, a práxis permite o movimento livre, criativo e autocriativo que enseja a transformação do mundo histórico e a transformação do próprio homem (BOTTOMORE, 1997). Não obstante esteja circunscrita aos limites do progresso técnico e à consciência possivel, a intensa atividade na web permite prosperar alguns êxitos. Para dar um exemplo, o ciberespaço, em especial, tem se tornado terreno de resistência ao elemento capital do sistema: o monopólio da propriedade dos meios de produção. A criação dos softwares livres procura enfrentar o controle exclusivo das grandes corporações sobre o mercado da informática, colocando o tema dos monopólios no âmbito do debate sobre democracia e direitos humanos. A indisciplina geral mediante a propriedade intelectual, evidenciada na prática da "pirataria" e do compartilhamento de músicas, livros e filmes, consegue burlar a vigilância da indústria cultural e, mesmo de forma limitada, socializar o conhecimento.

Outro aspecto que merece ser sublinhado diz respeito à formação de uma juventude que, interessada na ciência da internet, tem avançado na compreensão de sua estrutura de funcionamento para além do uso cotidiano e superficial. Nesse sentido, determinada "educação tecnológica", compartilhada em rede, tem permitido que parte da juventude trabalhadora alcance saberes que ultrapassam o simples manejo da máquina. Ainda que este seja um fenômeno incorporado pela lógica da acumulação, é também um elemento relacionado ao domínio da produção, à justa unidade teoria e prática do devir histórico.

Também vale ressaltar que, ao contrário do que afirmou Prudêncio (2008), as redes sociais têm sido terreno fértil para a realização de 
Ativismo de esquerda nas redes sociais: Contradições das novas trincheiras da luta política | Vanessa Tavares Dias

experimentos jornalísticos. Desde pelo menos o início dos anos 2000, um jornalismo desembaraçado das grandes empresas de comunicação passou a produzir notícias e informar ao público uma realidade omitida pelas mídias corporativas. No Brasil, essas experiências ganharam força a partir de 2013, tendo como um dos principais expoentes a Mídia Ninja (Narrativas Independentes, Jornalismo e Ação). Essas mídias passaram a revelar outras vozes que emergiram à cena política para contar as suas histórias, rompendo assim com uma forma hegemônica de se produzir informação (LAHORGUE; MAHEIRIE, 2019).

Enfim, o espaço virtual não se situa em dimensão autônoma em relação ao mundo da produção material e imaterial, da exploração do trabalho e da mercantilização da vida. Pelo contrário, os modernos instrumentos de comunicação e interação social são produtos da confluência entre avanços científico-tecnológicos capitalistas, transformações das relações sociais de produção, precarização das condições do(a) trabalhador(a) e surgimento de novas formas de intercâmbio social. A interseção desses aspectos consagra novos fluxos horizontais e reitera fluxos verticais de informação condizentes com as necessidades materiais e simbólicas do momento presente. O conteúdo do que é comunicado é, igualmente, produção social e material da ordem econômica, e está relacionada à ideologia dominante e à consciência possível. Todavia, é ainda práxis, através da qual despontam novas formas de socialização e de reelaboração de uma nova cultura.

\section{Do periodismo operário ao hashtag \#MariellePresente}

A oposição à ortodoxia dominante por meio da comunicação não nasce com a telemática. A história dos movimentos sociais e das organizações de esquerda, como observa Downing (2002), tem sido a de encontrar formas marginais e alternativas de comunicação para fazer frente à tirania e à exploração. Tal oposição, segundo o mesmo autor, tem ocorrido tanto pelas formas não midiáticas de comunicação (dança, teatro popular, música, poesia, grafite etc.), como pela palavra registrada e difundida em panfletos, brochuras, fitas de áudio e de vídeo. 
Ativismo de esquerda nas redes sociais: Contradições das novas trincheiras da luta políticaVanessa Tavares Dias

Thompson, em A Formação da Classe Operária Inglesa (2002), ressalta que, na primeira metade do século XIX, existia um radicalismo popular e uma efervescência intelectual presentes, notadamente, nos textos de periódicos radicais e nas manifestações da cultura de rua. No início do mesmo século, segundo o autor, lideranças da classe trabalhadora faziam uso de imprensa secreta, periódicos e folhetos anônimos para realizar educação política. Os textos eram lidos em bares para alcançar os diaristas analfabetos. Trabalhadores iletrados andavam quilômetros para ouvir um orador e muitos pediam a companheiros de trabalho para lerem periódicos em voz alta. "Liase o jornal nas pensões dos artífices, e nas reuniões politicas gastava-se um tempo imenso com a leitura de discursos e a aprovação de longas séries de resoluções" (THOMPSON, 2002, p. 305).

Foot Hardman (2002), ao analisar a "cultura de resistência” no Brasil através de situações concretas da luta operária, cita os periódicos Amigo do Povo e Aurora como expressões representativas da propaganda libertária do início do século $\mathrm{XX}^{11}$. O tabloide Amigo do Povo, conforme a mesma análise, apresentava um mosaico de textos e frases de pensadores e escritores com perspectivas heterogêneas, que compunham uma visão comum contra o poder estabelecido. Esses textos combinavam-se a outros de caráter anarquista, positivista e evolucionista que eram, em sua maioria, traduzidos de teóricos anarquistas. O periódico ainda incluía notas regulares sobre o movimento operário na Rússia, na Itália e na França. Esses aspectos demonstram uma importante interconexão global no âmbito do movimento anarquista:

Nesse sentido, percebe-se claramente a importância da imprensa operária como "material ideológico", nos termos de Gramsci, ou seja, como verdadeira correia de transmissão das ideologias internacionalistas do movimento operário por meio de intensa circulação e intercâmbio entre as lideranças anarquistas da Europa, América Latina e Brasil. Tal processo dava-se por meio da troca regular de periódicos, correspondência internacional, bibliotecas e notas bibliográficas, traduções de artigos e obras, viagens de lideranças etc. (FOOT HARDMAN, 2002, p. 311).

\footnotetext{
11 Gianotti (2007) afirma que, desde meados do século XIX até 1930, havia aproximadamente 500 jornais no Brasil que circulavam nas fábricas, canteiros de obras, portos e oficinas. Além das reinvindicações de direitos, os jornais publicavam temas centrais do anarquismo contra o capitalismo, a burguesia, a aristocracia, além de conter forte anticlericalismo. A partir de 1930, a imprensa anarquista sofre uma retração para dar lugar à imprensa comunista, que surge como instrumento de resistência à burguesia industrial e às oligarquias tradicionais. Mais tarde, nos anos da ditadura empresarial-militar, surge a imprensa chamada alternativa, cujo objetivo era resistir ao terrorismo de Estado. De acordo com o autor, foram criados entre 1965 e 1981 mais de 150 jornais que faziam oposição à ditadura.
} 
Ativismo de esquerda nas redes sociais: Contradições das novas trincheiras da luta política | Vanessa Tavares Dias

Desta forma, a resistência da classe trabalhadora tem contado, na História, com os seus próprios instrumentos de comunicação, por meio dos quais tem estabelecido debates e formação política, além de todo tipo de resistência à ordem constituída. Os periódicos provocavam debates intraclasse e estabeleciam interligação dos trabalhadores em âmbito internacional. Portanto, é possivel afirmar que a internet nada inventa nesse domínio.

Quais seriam, então, as especificidades das novas tecnologias para a luta da esquerda no atual contexto histórico?

Uma das primeiras variáveis a serem consideradas diz respeito à compreensão de quem são os sujeitos ativistas. As mudanças no mundo do trabalho e na produção assim como a complexificação da sociedade civil, ocorridas nas últimas décadas do século $\mathrm{XX}$, ocasionaram tanto $\mathrm{o}$ enfraquecimento das entidades de classe, como a multiplicação de organizações politicas e movimentos sociais em defesa de causas variadas. Nesse sentido, a classe em luta tem hoje uma configuração distinta daquela do passado. De mais a mais, o ativismo de esquerda desagregado e apartado de organismos políticos e de movimentos sociais orgânicos reforça a pulverização das lutas, tendo como efeito a ausência de um princípio norteador e unificador.

Há, também, diferenças significativas nas práticas do ciberativismo de esquerda em relação ao jornalismo operário. Para Sodré (2013), resulta das novas tecnologias um "ethos catártico e imaginariamente redentor da miséria e da exclusão sociais que tendem a agravar-se com a nova economia mundo (...)" (SODRÉ, 2013, p. 81). Nesse sentido, o ambiente virtual permite aos sujeitos, segundo o mesmo autor, encontrar formas compensatórias de solidariedade, que vão de uma religiosidade indefinida a uma interatividade democratista entre sujeitos afetivamente distantes. Essa militância, em muitos casos, não consegue levar o seu ativismo para além dos limites da comunicação em rede, o que a restringe exclusivamente aos debates informacionais. 
Ativismo de esquerda nas redes sociais: Contradições das novas trincheiras da luta políticaVanessa Tavares Dias

A despeito disso, o ativismo de esquerda também tem demonstrado grande capacidade de mobilização social, com amplo alcance nacional e internacional. A velocidade com que circula a informação e o repertório discursivo original a arregimentar para os combates constituem diferenças importantes frente às formas de comunicação do passado.

A década de 90 do último século - período em que as mídias sociais não tinham alcançado a popularidade atual -, foi marcada pela primeira grande mobilização feita pela internet por um movimento social revolucionário. De acordo com Abdel-Modeim (2002), o Exército Zapatista de Libertação Nacional (EZLN), por ocasião da ocupação de Chiapas, realizou intensa campanha, por meio de websites e correio eletrônico, com o propósito de reagir à violência do Estado mexicano contra os seus militantes. Organizações não governamentais em todo mundo, de acordo com a mesma autora, promoveram uma frente de denúncias sobre os abusos perpetrados pelas forças de repressão do governo de Ernesto Zedillo. Em pouco tempo, fotos e vídeos que apresentavam o dia a dia dos ocupantes chegavam às caixas de mensagens dos computadores de governos e entidades de direitos humanos. Em websites, galerias de fotos mostravam mulheres e crianças tentando impedir com seus próprios corpos que soldados de tropas de choque entrassem nas vilas, explicitando o conflito em imagens.

Daí em diante, o movimento ganhou visibilidade e conseguiu internacionalizar-se. A solidariedade aos zapatistas somou-se às diferentes bandeiras de resistência virtual - contra a repressão de minorias, contra o neocolonialismo e contra o neoliberalismo (ABDEL-MONEIM, 2002). Bringel e Muñoz (2010) consideram que a campanha internacional motivada pelo movimento zapatista conseguiu articular uma rede de resistência antiglobalização em todo o mundo. A atuação mais importante dessa rede, após o evento de Chiapas, ocorreu em 1999 durante a reunião da Cúpula da Organização Mundial do Comércio (OMC), em Seattle. Na ocasião, segundo os autores, quase cem mil manifestantes conseguiram paralisar a realização do encontro.

Em 2003, por ocasião da invasão estadunidense ao Iraque, as mobilizações on-line contra o imperialismo também conseguiram mobilizar 
Ativismo de esquerda nas redes sociais: Contradições das novas trincheiras da luta política | Vanessa Tavares Dias

ativistas em âmbito planetário. Naquele momento, conforme analisa Machado (2007), enquanto a mass media divulgava informações pró Estados Unidos, os bloggers, a imprensa alternativa, a mídia árabe e os coletivos sociais usavam a internet para divulgar notícias e imagens que eram ocultadas pelas agências internacionais de notícias. Em fevereiro daquele ano, segundo o mesmo autor, uma organização chamada MoveOn.org organizou um protesto que levou 250 mil pessoas às ruas de Nova Iorque. Durante a guerra, foram registrados ainda 100 mil ocorrências de hackerismo com motivação política.

O ano de 2011 foi um ano seminal para mobilizações convocadas pelas redes sociais. A chamada "Primavera Árabe", iniciada na região do Médio Oriente e da África do Norte, configurou-se, de maneira geral, como um movimento popular contra governos autocráticos, num cenário global de crises econômicas. Os manifestantes, segundo o blog sigaesquerda ${ }^{12}$, também fizeram uso intensivo das mídias sociais - Facebook, Twitter e Youtube -, com vistas a, entre outros aspectos, divulgar a repressão do Estado contra os insurgentes. Os protestos caracterizaram-se por resistência civil, envolvendo greves, manifestações, passeatas e comícios.

A "Primavera Árabe" foi apenas o início de uma onda de outras "primaveras" que atravessaram a Europa, os Estados Unidos e a América Latina. Ainda em 2011, ocorreram mobilizações na Grécia, na Espanha e em Portugal contra as medidas neoliberais de seus países e a intervenção da Troika ${ }^{13}$. Em setembro do mesmo ano, o Occupy Wall Street significou um movimento de resistência dos estadunidenses contra a poderosa influência do mercado financeiro nos rumos do país. No Chile, uma gigantesca mobilização de massa envolveu estudantes de todo o sistema educacional, tanto do setor público como do privado, que reivindicavam o fim da mercantilização da educação. Rapidamente, as informações sobre esse movimento se espalharam pelas redes sociais e alcançaram estudantes da América Latina e da Europa ${ }^{14}$,

$12<$ http://sigaesquerda.blogspot.com.br/2012/03/o-que-e-primavera-arabe.html>, acesso em: 03 abr. 2015 .

13 Troika refere-se ao grupo de trabalho constituído por Comissão Europeia, Banco Central Europeu e Fundo Monetário Internacional que impõem políticas de ajustes monetários aos Estados nacionais.

$14<$ http://operamundi.uol.com.br/conteudo/noticias/18090/estudantes+latino-

americanos+fazem+mobilizacao+continental+pela+educacao.shtml>, acesso em: 05/04/2015. 
Ativismo de esquerda nas redes sociais: Contradições das novas trincheiras da luta políticaVanessa Tavares Dias

que iniciaram novas ondas de mobilizações. A "primavera” brasileira ocorreu dois anos depois, em junho de 2013. Uma das características desse movimento foi a heterogeneidade das reivindicações, mas que expressavam preocupação com a diminuição de direitos sociais.

$\mathrm{Na}$ última década, tanto grupos organizados pró-Palestina como os próprios palestinos têm usado intensamente as redes sociais como instrumento de contrainformação. Após um dos ataques de Israel à Faixa de Gaza, que teve início em julho de 2014, circularam nas redes sociais vídeos que mostravam a truculência de soldados israelenses em abordagens a palestinos, imagens de hospitais, escolas e creches destruidos por bombas lançadas por Israel; uma sequência de imagens revelando o desespero de moradores de Gaza tentando escapar dos ataques aéreos; fotos impactantes de crianças mutiladas e mortas sob os olhares de parentes aterrorizados. Essas imagens causaram comoção em âmbito internacional e provocaram manifestações em todo o mundo ${ }^{15}$. Do oriente ao ocidente, milhares de pessoas, com cartazes, usando simbolos palestinos, protestaram em frente aos consulados, aos escritórios das Nações Unidas e às embaixadas israelenses e estadunidenses.

No Brasil, em 2012, as mídias eletrônicas noticiaram a invasão de pistoleiros à ocupação indígena do tekoha (território sagrado) Arroio Koral, em Mato Grosso do Sul, tornando pública a luta dos índios da nação GuaraniKaiowá. Naquele momento, constituiu-se forte solidariedade coletiva desencadeada, especialmente, após a circulação pelas redes sociais de uma carta redigida pelos indígenas por meio da qual declaravam a sua morte social. Ameaçados de despejo por ordem judicial, anunciaram:

De fato, sabemos muito bem que no centro desse nosso território antigo estão enterrados vários os nossos avôs e avós, bisavôs e bisavós, ali estão os cemitérios de todos nossos antepassados. Cientes desse fato histórico, nós já vamos e queremos ser morto e enterrado junto aos nossos antepassados aqui mesmo onde estamos hoje, por isso, pedimos ao Governo e Justiça Federal para não decretar a ordem

\footnotetext{
15 Foram registradas manifestações em diferentes cidades da França, Espanha, Estados Unidos, Afeganistão, India, Coreia do Sul, Finlândia, Turquia, Brasil, Países Baixos, Japão, África do Sul, Indonésia, Canadá, Maldivas, Tunísia, Chile, Alemanha, Austrália, Bélgica, Polônia, Taiwan, República Dominicana, Suiça, Senegal, Marrocos, Reino Unido, México, Honduras, Itália, Dinamarca, Macedônia, Argentina, Líbano, Escócia, Irlanda e Israel. Essas manifestações foram noticiadas pelas mídias alternativas e registradas por um tumblr, plataforma aberta para publicações, que também funciona em forma de rede, e que permite que as pessoas publiquem documentos de naturezas diversas. Imagens disponiveis em http://theworldstandswithpalestine.tumblr.com/Acesso em: dez. 2014.
} 
Ativismo de esquerda nas redes sociais: Contradições das novas trincheiras da luta política | Vanessa Tavares Dias

de despejo/expulsão, mas solicitamos para decretar a nossa morte coletiva e para enterrar nós todos aqui. Pedimos, de uma vez por todas, para decretar a nossa dizimação/extinção total, além de enviar vários tratores para cavar um grande buraco para jogar e enterrar os nossos corpos. Esse é nosso pedido aos juízes federais ${ }^{16}$.

Logo, a extensão Guarani Kaiowá foi incluída ao sobrenome de milhares de usuários do Facebook e do Twitter, enquanto fotos pessoais publicadas nos perfis iam sendo aos poucos substituídas por fotos de crianças e mulheres indígenas. Os hashtags \#SouGuaraniKaiowa e \#SomosTodosGuaraniKaiowa, recurso de busca por assunto e medida nos trending topics do Twitter ${ }^{17}$, indicavam a incorporação da identidade indigena por diferentes sujeitos, determinados a tratar o conflito como problema coletivo.

Outro aspecto que tem mobilizado a militância de esquerda do país está relacionado ao aumento da violência do Estado contra a população pobre e negra das grandes cidades. O caso Amarildo talvez tenha sido, até o momento, um dos mais emblemáticos no que respeita à intensidade de publicações e debates online. Em 14 de julho de 2013, o ajudante de pedreiro Amarildo de Souza foi abordado por policiais na comunidade da Rocinha, no Rio de Janeiro, e levado para “averiguações”. Depois desse episódio, Amarildo desapareceu. O desaparecimento desse trabalhador significou, naquele momento, uma espécie de "gota d’água" nas reiteradas violações de direitos da população pobre, levando a uma onda de mobilizações online e off-line, convocadas por ativistas de esquerda. O hashtag \#OndeEstáAmarildo? espalhou-se pela web. Seu nome foi extraordinariamente repetido nas disputas de narrativas nas redes sociais. Amarildo deixou o anonimato, que tipifica o sujeito imerso na massa popular, para tornar-se símbolo das lutas em defesa de todos os sujeitos negros e pobres, vilipendiados e torturados pelo Estado capitalista.

\footnotetext{
16 Trecho parcial da carta, disponivel na integra em https://cimi.org.br/2012/10/34104/, acesso em: 06/06/2017.

$17 \mathrm{Na}$ rede social Twitter, as palavras mais postadas pelos usuários e usuárias são listadas em tempo real, com o fim de monitorar o conteúdo e apresentar os principais assuntos do momento. Para isso dáse o nome de trending topics.
} 
Ativismo de esquerda nas redes sociais: Contradições das novas trincheiras da luta políticaVanessa Tavares Dias

Ainda em 2013, um mês antes do desaparecimento de Amarildo, o catador de latinhas e morador de rua Rafael Vieira Braga foi abordado e detido por dois inspetores da Polícia Civil quando passava por uma manifestação política no centro da cidade do Rio de Janeiro. Sob a alegação de que portava produtos de limpeza, que poderiam ser utilizados como matéria-prima para confecção de coquetel molotov, Rafael foi preso e condenado a quatro anos de prisão. Tornou-se, a partir de então, o único preso político das manifestações de junho de 2013. Uma vez mais, contra a politica higienista do Estado capitalista, o ativismo de esquerda encapou outra campanha pela internet. Organizações de direitos humanos nacionais e internacionais, parlamentares de partidos de esquerda, militantes de diferentes coletivos efetuaram uma série de publicações nas redes sociais pela sua soltura. O hashtag \#LibertemRafaelBraga, fotos, charges e desenhos de Rafael foram reproduzidos centenas de milhares de vezes. A campanha ganhou as ruas e os muros das cidades.

Em 2015, outra campanha que ganhou as redes sociais no Brasil, e obteve resultados importantes, chamou-se \#meuprimeiroassédio. Motivadas por uma situação de assédio vivida por uma criança num programa de TV, milhares de mulheres iniciaram, no Facebook, uma série de denúncias sobre situações de assédio sexual, sofridas por elas ainda na infância. As denúncias encorajaram rapidamente um maior número de sujeitos femininos, vitimados pelo abuso, a confessarem o inconfessável. Segundo Mota et. al (2017), oitenta e duas mil mensagens foram publicadas nesta campanha. A repercussão foi tão grande que, segundo os(as) mesmos(as) autores(as), repetiu-se na GrãBretanha, Estados Unidos, Chile, Portugal e Holanda. Uma vez mais, os debates informacionais resultaram na socialização de experiências pessoais, transformando-as em experiências coletivas. A cultura da naturalização do abuso foi desvelada e denunciada.

No dia 14 de março de 2018, a vereadora Marielle Franco, do Partido Socialismo e Liberdade (PSOL), e seu motorista, Anderson Gomes, foram executados no centro da cidade do Rio de Janeiro, quando voltavam de um evento com mulheres do coletivo Casa das Pretas. A vereadora, quinta mais votada na eleição municipal do Rio de Janeiro em 2016, se definia como 
Ativismo de esquerda nas redes sociais: Contradições das novas trincheiras da luta política | Vanessa Tavares Dias

mulher negra, feminista, militante de direitos humanos e representante dos estratos mais pobres da sociedade. Como observa Rocha (2019), ela conseguira atrair para o seu mandato uma base social diversa, formada tanto por moradores de favelas, como intelectuais, integrantes do movimento negro, mulheres, jovens universitários que identificavam na vereadora a oportunidade de transformação da arquitetura da política institucional.

Marielle Franco defendia a desmilitarização da polícia militar e o fim da criminalização dos pobres. A sua atuação na Câmara de Vereadores enfrentava não apenas os grupos criminosos acolhidos pelo Estado, como os próprios aparelhos de repressão da ordem política, considerados os responsáveis pelo assassinato em massa de jovens negros e pobres no país. $\mathrm{Na}$ mesma direção, sua vereança denunciava as péssimas condições de trabalho dos policiais, que também são frequentemente mortos em confrontos com o crime organizados (FERREIRA et. al., 2018).

Desde o dia do seu assassinato, espalham-se postagens emocionadas sobre Marielle e Anderson; fotos de perfis do Facebook foram substituídas por fotos de Marielle; e persiste, desde então, a interrogação "Quem mandou matar Marielle e Anderson?" e as hashtag \#MariellePresente e \#JustiçaParaMarielleEAnderson. Jornalistas, personalidades públicas e ciberativistas de esquerda têm feito uso incansável das redes sociais para denunciar a execução da vereadora e de seu motorista. Conforme Almeida et. al. (2018), um estudo feito pela Diretoria de Análise de Políticas Públicas (DAPP) da Fundação Getúlio Vargas (FGV) identificou, dois dias após o assassinato, 1,16 milhão de menções à Marielle e Anderson no Twitter. $\mathrm{O}$ mesmo instituto, na época do crime, constatou que a hashtag \#mariellepresente foi a mais utilizada nesse microblog, aparecendo em cerca de 150 mil postagens, seguida das hashtags \#mariellefranco e \#nãofoiassalto, presentes em 34 mil postagens.

A repercussão do caso nas redes sociais inspirou as muitas homenagens feitas à Marielle em universidades, escolas, centros culturais, assim como influenciou mobilizações nas ruas do país e do mundo, além das homenagens que recebeu de artistas internacionais e parlamentares de outros 
Ativismo de esquerda nas redes sociais: Contradições das novas trincheiras da luta políticaVanessa Tavares Dias

estados e países. A execução da vereadora e de seu motorista causou consternação profunda em parte da sociedade brasileira, e esta comoção foi propagada amplamente pelas redes sociais, causando impactos em pessoas que nunca tinham ouvido falar dela. Este fenômeno, por sua vez, ocasionou o reverso: segundo Ferreira et. al., (2018), Marielle foi alvo de uma profusão de notícias falsas. As fake news buscavam relacioná-la com o crime organizado, numa clara tentativa de desmoralizá-la e de naturalizar o seu assassinato como são naturalizados os assassinatos de todos os pretos e pobres do país. Um caso emblemático, como lembram os autores (FERREIRA et. al., 2018), envolveu a desembargadora do Tribunal de Justiça do Rio de Janeiro (TJ-RJ) Marilia Castro Neves. Em sua conta de uma rede social, a magistrada afirmou que Marielle Franco era tão somente um "cadáver comum", como todos aqueles associados a bandidos ${ }^{18}$.

Depois dessas campanhas, outras com igual relevância foram empreendidas, com destaque para a campanha \#elenão, movimento de inspiração feminista contra a candidatura de Jair Bolsonaro à presidência do Brasil, que começou nas redes e ganhou as ruas de todo o país. No entanto, a despeito de toda mobilização e da possibilidade de disseminação de ideias do campo da esquerda anticapitalista, revolucionária ou reformista, e de as redes sociais terem conseguido ampliar a visibilidade e a solidariedade global em torno dos movimentos sociais e dos grupos subalternizados, o conjunto dessas lutas não foi capaz de interromper a onda reacionária que alcançou o mundo e, particularmente, o Brasil.

$\mathrm{Na}$ época presente, como afirmamos anteriormente, o pensamento reacionário também encontrou abrigo nas redes sociais, fenômeno que ocorre ao mesmo tempo em que a direita se revigora e triunfa em diferentes países. Conforme observou Löwy (2015), em 2014, o avanço da extrema-direita por quase todo o continente europeu não encontra precedentes desde os anos 30. A direita fascista e xenofóbica aumentou consideravelmente o número de adesão popular, alcançando de 25 a 30\% de votos do eleitorado, especialmente no Reino Unido, Dinamarca e França. Para o mesmo autor (LÖWY, 2015), o

\footnotetext{
18 Quando esse texto foi finalizado, os mandantes do assassinato não haviam sido identificados.
} 
Ativismo de esquerda nas redes sociais: Contradições das novas trincheiras da luta política | Vanessa Tavares Dias

que diferencia os dois campos da direita mundial é que a burguesia liberal tende a apoiar a globalização capitalista de cunho neoliberal, enquanto os adeptos da extrema-direita, malgrado a sua variedade interna, aproximam-se da defesa do nacionalismo econômico, acompanhada do anticomunismo, xenofobia, racismo, ódio aos imigrantes, ódio aos ciganos e islamofobia (esta, em substituição ao antissemitismo). Em geral, sua retórica é complementada por uma suposta preocupação com os pobres e com a classe trabalhadora (branca) nacional (LÖWY, 2015).

Essa vaga reacionária, como observa Löwy (2015), contamina as ideias tanto da direita "clássica" quanto de uma parte da esquerda social-liberal, que acabam por acompanhar tendências ideológicas de natureza fascista. No Brasil, o movimento de extrema-direita tem mobilizado membros da classe média e alcançado parte da juventude. Nos últimos anos e, sobretudo, durante e após as eleições de 2014, foi possível perceber, nas redes sociais, a intensificação do discurso de ódio contra movimentos sociais, ataques constantes à democracia e exaltação à volta dos militares ao poder. O desfecho dessa mobilização foi a eleição presidencial, em 2018, de um candidato com ideias claramente antidemocráticas, para dizer o mínimo.

De acordo com Silva (2017), o pensamento de direita nunca deixou de existir, nem no Brasil, nem no mundo. Todavia, nos últimos anos, se complexificou e capilarizou, tornando-se mais próximo às massas. Grupos de direita e figuras públicas encontraram, no atual contexto, um ambiente propício para encampar abertamente o discurso e a identidade de direita contra os direitos humanos, especialmente contra os direitos de Lésbicas, Gays, Bissexuais, Transgêneros, Intersexuais, Queers e mais (LGBTQI+). Tal posicionamento, segundo a mesma autora (2017), não está desprovido de estratégia política. A incorporação de pautas fascistas, por uma parte da direita, tem relação com a dificuldade que esse campo político encontra para convencer as massas a aceitarem as politicas antipopulares neoliberais. Por isso, essa direita acaba por recair em aspectos morais próprios do fascismo como forma de se aproximar de certa dimensão da mentalidade do senso comum, conseguindo com isso alcançar uma parte considerável da sociedade. 
Ativismo de esquerda nas redes sociais: Contradições das novas trincheiras da luta políticaVanessa Tavares Dias

Esse novo impulso das ideias de direita tem a prerrogativa de contar com a mídia burguesa e, também, com as múltiplas possibilidades de construção de conteúdos nas redes sociais. Desta forma, a voz da direita adquire vantagem em relação aos grupos à esquerda, isto porque acaba amplificada pela associação entre as mídias tradicionais e as novas tecnologias de comunicação. E, mesmo nesse caso, quando lhes convém, segundo Silva (2017), os grupos à direita podem confrontar as mídias burguesas, classificando-as de "esquerdistas", voltando-se completamente para a internet. A mesma autora afirma que certas correntes da "nova" direita têm recorrido à linguagem própria de viodegames, vloggers e youtubers, demonstrando que adota uma tática discursiva nos debates virtuais. Os militantes deste campo ideológico também têm sido bem sucedidos na convocação de mobilizações de rua mediante pautas conservadoras e, em alguns casos, paradoxalmente antidemocráticas.

Partindo do que foi exposto, as neotecnologias de comunicação podem ser consideradas parte do progresso tecnológico a serviço do capital, tendo o capital o domínio sobre os seus protocolos, os seus códigos de funcionamento e os seus conteúdos. A comunicação em rede está inserida nesse espaço governado pela classe dominante, não sendo possível, portanto, tratar a web como terreno pré-determinado de livre atividade social, do pensamento autônomo ou revolucionário. O ciberativismo de esquerda realiza-se, portanto, dentro de um campo de interações controlado, com alcance limitado, permeado pela hegemonia dominante, desequilibrado pela força de grupos que detêm recursos econômicos e simbólicos para participar das disputas. Como no materialismo histórico, o mundo material e a ideologia não estão dissociados, a batalha de ideias é atravessada pelos limites da arquitetura tecnológica, pelo contexto de reprodução capitalista e pelo conjunto de forças colocadas na arena politica.

\section{Considerações finais}

Historicamente, o desenvolvimento tecnológico evoca sonhos de um mundo constituído pela comunicação livre e democrática. Conforme observa Lévy (LEMOS; LÉVY, 2010), a arte, a ciência, o jornalismo e a publicidade são responsáveis por difundir utopias e distopias sobre as novas tecnologias, 
Ativismo de esquerda nas redes sociais: Contradições das novas trincheiras da luta política | Vanessa Tavares Dias

estabelecendo profecias de um futuro quimérico. "Foi assim com o telégrafo e a estrada de ferro; com o rádio, o telefone, os navios e as autoestradas; com a TV, os aviões, a viagem à lua e a Internet" (LEMOS; LÉVY, 2010, p. 21). Reis e Barros (2011) afirmam que a literatura pioneira nos estudos sobre o ciberespaço fez previsões otimistas sobre esse novo campo de comunicação global, avaliando que em médio prazo ele promoveria a aproximação de diferentes sujeitos em todo o mundo, aumentaria o acesso ao conhecimento variado, transformaria as formas de sociabilidade e, na esfera política, acabaria com toda e qualquer forma de tirania.

No caso da análise aqui apresentada, restam mais perguntas do que respostas, como, por exemplo: A guerra de posição ocupada pela militância de esquerda nas mídias sociais permite colocar em xeque as estratégias de controle e de produção de consenso das mídias corporativas? Qual público essa comunicação é capaz de alcançar? Qual seria a influência efetiva da comunicação mediada pela internet nas lutas sociais e politicas? Com Tilly e Wood (2010), as novas tecnologias de comunicação têm um impacto mais efetivo na ação coletiva do que as tecnologias do passado?

Gramsci, através da filosofia da práxis e, por conseguinte, da dialética base-superestrutura, unidade entre teoria e prática, propõe a análise das conexões orgânicas entre esferas contraditórias da realidade. A sua filosofia, como expusemos anteriormente, realça o nexo orgânico fundamental entre as relações materiais de produção e a "vontade humana", a ideologia e a cultura. Em outras palavras, o comunista italiano enfatiza, entre outros aspectos, a recorrência histórica das relações capitalistas de produção, a perpetuação da exploração do trabalho e a coisificação do homem, mas ao mesmo tempo, reconhece que contraditoriamente ao passado, uma força que se move em direção ao futuro é capaz de construir conhecimentos alternativos, uma linguagem nova, outra cultura. Essas experiências deslocam-se da abstração e se concretizam nas práticas da militância de esquerda nas redes sociais, que buscamos salientar aqui.

$\mathrm{Na}$ exata relação base-superestrutura, Gramsci (2004) entende que a máquina, para além de propriedades físico-químicas ou mecânicas, é objeto 
Ativismo de esquerda nas redes sociais: Contradições das novas trincheiras da luta políticaVanessa Tavares Dias

de determinadas forças sociais e expressa relações sociais, que correspondem a um determinado período histórico. A tecnologia, por sua vez, segundo o mesmo pensador, é mediadora da relação homem-realidade (homem-homem, homem-natureza); é, por conseguinte, fundamento determinado da práxis. Sendo assim, através da tecnologia, entre outras variantes, o homem transforma a natureza, a realidade social e a si mesmo.

Pela filosofia da práxis é possivel dar um sentido, ainda que preliminar, à resistência de esquerda nas redes sociais. A teoria dialética de Gramsci é capaz de revelar que a estrutura social e econômica expressa os limites materiais e ideológicos que governam o mundo social, seja online ou off-line. No ciberespaço e nas multiplataformas de comunicação, os monopólios digitais, o controle das informações e a mercantilização do mundo virtual engendram as relações em diferentes dimensões. No entanto, uma força antitética, que não esmorece diante do aperfeiçoamento das formas de exploração do capitalismo avançado, é capaz de encontrar nesse mesmo campo de relações estratégias novas de enfrentamento, que têm como alvo desde os próprios monopólios das grandes empresas até a reelaboração da linguagem, a reestruturação das estratégias discursivas e o repertório de lutas, demonstrando que a internet se configura uma trincheira de resistências, gerando novas exigências culturais e políticas. As lutas sociais renovadas operam sob o domínio das relações de produção, das leis da acumulação e das ideias da classe dominante, mas são combates que fazem avançar as dinâmicas e as potencialidades da história.

\section{Referências:}

ABDEL-MODEIM, Sarah Grussing. O Ciborgue Zapatista: tecendo a poética virtual de resistência no Chiapas cibernético. Revista Estudos Feministas [online], v.10, n.1, p. 39-64, Jan. 2002. Disponivel em: $<$ http://dx.doi.org/10.1590/S0104-026X2002000100003> Acesso em: $15 / 08 / 2014$.

ALLCOTT, Hunt; GENTZKOW, Matthew. Social Media and Fake News in the 2016 Election. Journal of Economic Perspectives, vol. 31, n 2, p. 211-236, Spring, 2017.

Disponível

em: 
Ativismo de esquerda nas redes sociais: Contradições das novas trincheiras da luta política | Vanessa Tavares Dias

$<$ https://pubs.aeaweb.org/doi/pdfplus/10.1257/jep.31.2.211> Acesso em: $29 / 01 / 2019$.

ALMEIDA, Franco Benites de; PIMENTA, Vitor de Oliveira; DELlARMELIN, Mateus Luan \#JustiçaParaMarielleEAnderson: uma análise da rede no Twitter. Temática. NAMID/UFPB. Ano XIV, n. 12. Dez. 2018. Disponível em: $<$ http://periodicos.ufpb.br/ojs2/index.php/tematica $>$ Acesso em: $30 / 01 / 2019$.

ANTUNES, Ricardo. O século XX e a era da degradação do trabalho. In: SILVA, Josué Pereira da. (org.). Por uma sociologia do século XX. São Paulo: Ed AnnaBlume, 2007, p. 21-35.

BOBBIO, Norberto. Direita e Esquerda: razões e significados de uma distinção política. São Paulo: Ed. UNESP, 2011.

BOTTOMORE, Tom. Dicionário do Pensamento Marxista. Rio de Janeiro: Jorge Zahar Editor, 1997.

BOVET, Alexandre; MAKSE, Hérnan A. Influence of fake news in Twitter during the 2016 US presidential election. Nature Communications, v. 10, n $7, \quad$ p. 1-14, jan. 2019. Disponivel em: $<$ https://www.nature.com/articles/s41467-018-07761-2.pdf $>$ Acesso em: $31 / 01 / 2019$.

BRINGEL, Breno; MUÑOZ, Enara Echart. Dez anos de Seattle, o movimento antiglobalização e a ação coletiva transnacional. Ciências Sociais Unisinos, São Leopoldo, v. 46, n. 1, p. 28-36, jan./abr. 2010. Disponivel em: $<$ http://revistas.unisinos.br/index.php/ciencias_sociais/article/viewFile/16 8/38> Acesso em: 20/01/2015.

CASTELLS, Manuel. A sociedade em rede. A Era da Informação: economia, sociedade e cultura. Vol. 1. São Paulo: Ed. Paz e Terra, 2012.

A Galáxia da Internet. Reflexões sobre a internet, os negócios e a sociedade. Rio de Janeiro: Ed. Zahar, 2003.

DOWNING, John D. H. Mídia Radical. Rebeldia nas Comunicações e Movimentos Sociais. São Paulo: Ed. SENAC, 2002.

FERRARA, Emilio; VAROL, Onur; DAVIS, Clayton; MENCZER, Filippo; FLAMMINI, Alessandro. The rise of social bots. Communications of the ACM, v. 59, n. 7, p. 96-104. July/November, 2016. Disponivel em: <https://dl.acm.org/ citation.cfm?id=2818717\&picked=formats $>$ Acesso em: 07/02/2019 
Ativismo de esquerda nas redes sociais: Contradições das novas trincheiras da luta políticaVanessa Tavares Dias

FERREIRA, Anderson; FERREIRA, Cristiane da Silva; CHAVES, Ramon Silva. As práticas discursivas da violência nas mídias digitais: Marielle Franco, presente... No espaço discursivo êmico. Revista (com) textos linguísticos, Vitória, v. 12, n. 22, 2018.

FOOT HARDMAN, Francisco. Nem Pátria, Nem Patrão. São Paulo: Ed. Unesp, 2002.

GIANOTTI, Vito. História das Lutas dos Trabalhadores no Brasil. Rio de Janeiro: Ed. Mauad X, 2007.

GRAMSCI, Antonio. Cadernos do Cárcere. Vol. 1, Rio de Janeiro: Ed. Civilização Brasileira, 2004.

Cadernos do Cárcere. Vol. 3, Rio de Janeiro: Ed. Civilização Brasileira, 2007a.

Cadernos do Cárcere. Vol. 4, Rio de Janeiro: Ed. Civilização Brasileira, 2007b.

GROHMANN, Rafael. Marx de volta? Na Comunicação? Revista Eletrônica do Programa de Pós-Graduação em Mídia e Cotidiano, v. 4, n.4, p 213-231, Jun. 2014. Disponivel em: <http://periodicos.uff.br/midiaecotidiano/article/view/9716/6842> Acesso em: $14 / 02 / 2015$.

KATZ, Claudio. Discusiones marxistas sobre tecnologia, Teoría. Razón y Revolución, p. 1-31, n.3, Invierno 1997. Disponível em: <http://revistaryr.org.ar/index.php/RyR/article/view/465/480> Acesso em: $27 / 12 / 2014$.

LAHORGUE, Josiele Bené; MAHEIRIE, Kátia. A produção de uma vida coletiva: a Rede Mídia Ninja como espaço de existir e resistir. Psicologia Politica. vol. 19. $\mathrm{n}^{\mathrm{o}}$ 45. p. 229-243, mai./ago. 2019. Disponível em: <http://pepsic.bvsalud.org/pdf/rpp/v19n45/v19n45a07.pdf>_Acesso em: $26 / 05 / 2020$.

LEMOS, André; LÉVY, Pierre. O futuro da internet. Em direção a uma ciberdemocracia planetária. São Paulo: Ed. Paulus, 2010.

LÉVY, Pierre. Cibercultura. Lisboa: Ed. Instituto Piaget, 1997.

LIGUORI, Guido; VOZA, Pasquale. Dicionário Gramsciano (1926-1937). São Paulo: Boitempo Editorial, 2017.

LÖWY, Michel. Conservadorismo e extrema-direita na Europa e no Brasil. Revista Serv Soc. Soc., São Paulo, n. 124, p. 652-664, out./dez. 2015. 
Ativismo de esquerda nas redes sociais: Contradições das novas trincheiras da luta política | Vanessa Tavares Dias

Disponivel em: <http://www.scielo.br/pdf/sssoc/n124/0101-6628-sssoc124-0652> Acesso em: 24/08/2017.

MACHADO, Jorge Alberto S. Ativismo em rede e conexões identitárias: novas perspectivas para os movimentos sociais. Sociologias, Porto Alegre, ano 9, n. 18, p 248-285, jul./dez. 2007. Disponivel em: <https://seer.ufrgs.br/sociologias/article/view/5657/3256> Acesso em: 20/06/2015.

MAGALINE, A. D. Luta de classes e desvalorização do capital. Lisboa: Moraes Editores, 1977.

MARX, Karl; ENGELS, Friedrich. O Manifesto do Partido Comunista. São Paulo: Boitempo Editorial, 2010.

Editoral, 2007.

A Ideologia Alemã. São Paulo: Boitempo

MOTA, Camila; FIAMMA, Lira; MOROSINI, Pedro; TEIXEIRA, Carla. O uso de Hashtags no Facebook e a Repercussão da Campanha \#Meuprimeiroassédio. Intercom, XIX Congresso de Ciências da Comunicação na Região Nordeste, Fortaleza, Ceará, 29/06 a 01/07/2017. Disponível em: <http:/ /www.portalintercom.org.br/anais/nordeste2017/resumos/R570295-1.pdf> Acesso em: 01/11/2017.

PARISER, Eli. O filtro invisivel: o que a internet está escondendo de você. Rio de Janeiro: Ed. Zahar, 2012.

PRUDÊNCIO, Kelly. Jornativismo: CMI e o ativismo online. Aurora: Revista de Arte, Midia e Politica, São Paulo, n. 2, p. 68-79, 2008. Disponivel em: <https://revistas.pucsp.br/aurora/article/view/6358/4661> Acesso em: $15 / 09 / 2014$.

REHMAN, Ikhlaq ur. Facebook-Cambridge Analytica data harvesting: What you need to know. Library Philosophy and Practice (e-journal). 2497, 2019. Disponivel em <https://digitalcommons.unl.edu/libphilprac/2497> Acesso em: 25/05/2020.

REIS, Lucas.; BARROS, Samuel. Internet e Revolução no Egito: o uso de sites de redes sociais durante a convulsão social que derrubou o governo ditatorial egípcio em 2011. Anais do XI Congresso Luso Afro Brasileiro de Ciências Sociais. Congresso do Conlab, XI, Salvador, 2011. Disponivel em: <https://www.researchgate.net/profile/Samuel_Barros2/publication/26673 7930_Internet_e_Revolucao_no_Egito_O_Uso_de_Sites_de_Redes_Sociais_Dur ante_a_Convulsao_Social_que_Derrubou_o_Governo_Ditatorial_Egipcio_em_2 011/links/543a36760cf2d6698be173e0.pdf> Acesso em: 15/02/2015. 
Ativismo de esquerda nas redes sociais: Contradições das novas trincheiras da luta políticaVanessa Tavares Dias

ROCHA, Lia de Mattos. A vida e as lutas de Marielle Franco. Em Pauta. Rio de Janeiro, n. 42, v. 16, p. 274-280, 2018. Disponivel em: <https://www.epublicacoes.uerj.br/index.php/revistaempauta/article/view/39439/27898> Acesso em: 07/02/2019.

SANTOS, Laymert Garcia dos. A informação após a virada cibernética. In: SANTOS, Laymert. Garcia dos; KEHL, Maria Rita; KUCINSKI, Bernardo; PINHEIRO, Walter (orgs.). Revolução tecnológica, internet e socialismo. São Paulo: Fundação Perseu Abramo, 2003.

SEVERO, Denise Osório; HOEFEL, Maria da Graça Luderitz; SHIMIZU, Helena. Redes Sociais, Facebook e debate politico: olhares dos movimentos sociais. Ciências Sociais Unisinos. São Leopoldo, Vol. 53, N. 2, p. 194-201, mai./ago. 2017. Disponivel em <https://www.redalyc.org/pdf/938/93853317004.pdf $>$ Acesso em: $14 / 05 / 2020$.

SILVA, Carla Luciana Souza da. Mídia e ascensão conservadora. Argumentum, Vitória, v. 9, n. 2, p. 172-182, mai./ago. 2017. Disponível em: <https://www.redalyc.org/pdf/4755/475555301015.pdf> Acesso em: $25 / 01 / 2018$.

SILVEIRA, Sérgio Amadeu da. Para analisar o poder tecnológico como poder politico (2011). In: SILVEIRA, Sérgio Amadeu; BRAGA, Sérgio; PENTEADO, Cláudio (orgs.). Cultura, Politica e Ativismo nas redes digitais. São Paulo: Ed. Fundação Perseu Abramo, 2014.

SODRÉ, Muniz. Antropológica do Espelho. Uma teoria da comunicação linear e em rede. Petrópolis: Ed. Vozes, 2013.

THOMPSON, Edward Palmer. A Formação da Classe Operária Inglesa. Vol. III. Rio de Janeiro: Ed. Paz e Terra, 2002.

TILLY, Charles; WOOD, Lesley J. Los movimientos sociales, 1768 - 2008. Desde sus origenes a facebook. Barcelona: Ed. Crítica, 2010.

WILLIAMS, Raymond. Cultura e Materialismo. São Paulo: Ed. UNESP, 2011. WOLFF, Simone. O "trabalho informacional" e a reificação da informação sob os novos paradigmas organizacionais. In: ANTUNES, Ricardo; BRAGA, Rui (orgs.). Infoproletários. Degradação real do trabalho virtual. São Paulo: Boitempo Editorial, 2009.

WOOLLEY, Samuel C., GUILBEAULT Douglas R. Computational Propaganda in the United States of America: Manufacturing Consensus Online. Computational Propaganda Research Project. University of Oxford, 2017. Disponivel em: <http://comprop.oii.ox.ac.uk/wpcontent/uploads/sites/89/2017/06/Comprop-USA.pdf> Acesso em: $31 / 01 / 2019$. 